\title{
DRUŽBENI PROIZVOD SLOVENSKIH MEST
}

\author{
Igor Vrišer
}

Izvleček

UDK 911.375:330.54=863(497.4)

Na podlagi podatkov o družbenem proizvodu ustvarjenem v slovenskih mestih l. 1990, ki jih je zbral Zavod Republike Slovenije za statistiko, je prikazan: 1. pomen in delež v mestih ustvarjenega družbenega proizvoda v Sloveniji, 2. koliko družbenega proizvoda je prišlo na mestnega oziroma podeželskega prebivalca, 3. katere dejavnosti so največ prispevale $k$ ustvarjenemu družbenemu proizvodu, 4.izvedena je bila funkcijska opredelitev mest glede na dejavnostno strukturo v mestih ustvarjenega družbenega proizvoda in 5. primerjava s podobno analizo iz leta 1966 je pokazala spremembe v pomenu mest, ki so nastale pod vplivom povojnega družbenoekonomskega razvoja.

Ključne besede: Družbeni proizvod, Slovenija, dejavnostna sestava mest.

\section{GROSS DOMESTIC PRODUCT OF SLOVENIAN TOWNS}

\section{Abstract}

On the basis of data on the GDP produced in Slovenian towns in 1990, gathered by the Statistical Office of the Republic of Slovenia, the following topics are presented: (1) the importance and percentage of Slovenian GDP produced in towns; (2) the percentage of GDP per an urban or rural inhabitant; (3) the activities which have contributed the most to the produced GDP; (4) a functional definition of towns was made according to the activity structure (primary, secondary, tertiary, quaternary) of the GDP produced in towns; (5) a comparison with a similar analysis of 1966 showed changes in the significance of towns, which was due to the influence of the post-War socio-economic development.

Key words: GDP; Slovenia, Activity structure of towns.

* Dr., prof., v pokoju, akademik, Oddelek za geografijo, Filozofska fakulteta Univerze v Ljubljani, Aškerčeva 2, SI 1000 Ljubljana, Slovenija 
Z letom 1991 se je v Republiki Sloveniji končalo obdobje socialistične družbene ureditve. Restitucija kapitalističnega sistema in izvedena osamosvojitev Slovenije pomenita izjemen družbeni prelom, ki ga bomo v zgodovini, geografiji, družboslovju, ekonomiji itd. podobno vrednotili kot npr. 1. 1918, ko se je Slovenija izločila iz Avstroogrske, ali pa 1. 1945, ko je pričela socialistična era. S tem letom se je pričelo uvajati nove gospodarske in statistične instrumente, ki ustrezajo tržnemu gospodarjenju in slede metodam razvitega kapitalističnega sveta, še posebej Evropski Uniji, žal pa niso vedno primerljivi s prejšnjimi.

Navedeno leto je glede na to zelo primerno bodisi za različne analize družbenih in gospodarskih razmer v preteklem petinštiridesetletnem obdobju ali pa kot izhodišče za ocenjevanje razvoja osamosvojene Slovenije. $V$ pričujoči študiji smo poskušali na podlagi gradiva o ustvarjenem družbenem proizvodu napraviti krajše ovrednotenje vloge oziroma pomena slovenskih mest ob koncu socialističnega obdobja. V njem smo prikazali, kolikšen delež ustvarjenega družbenega proizvoda je nastajal v mestih in koliko na podeželju, katere dejavnostne skupine so največ prispevale in kakšna je bila njegova dejavnostna sestava po slovenskih mestih. Izsledki naj bi podali oceno, kako globoko je segla povojna urbanizacija in industrializacija in kakšno težo ji lahko pripišemo; hkrati pa bi bili uporabno izhodišče za morebitne kasnejše primerjave, ki bodo analizirale slovenski družbeni razvoj po 1. 1990.

Gradivo. Podatke o družbenem proizvodu ustvarjenem v mestih Republike Slovenije za 1.1990 je zbral Zavod RS za statistiko po tedaj veljavni metodologiji po naročilu avtorja. Gradivo je obsegalo naslednje podatke: 1 . družbeni proizvod po občinah in 2 . družbeni proizvod po področjih dejavnosti ustvarjen $v$ mestih in drugih mestnih naseljih Republike Slovenije (Zavod RS za statistiko, 1994). Za vsako teritorialno enoto so bili podatki razčlenjeni na 14 panog: 01 industrija in rudarstvo, 02 kmetijstvo in ribištvo, 03 gozdarstvo, 04 vodno gospodarstvo, 05 gradbeništvo, 06 promet in zveze, 07 trgovina, 08 gostinstvo in turizem, 09 obrt in osebne storitve, 10 stanovanjska in komunalna dejavnost, 11 finance in druge poslovne storitve, 12. izobraževanje in kultura, 13 zdravstvo in socialno varstvo in 14 družbene organizacije in skupnosti. Vrednost ustvarjenega družbenega proizvoda je bila podana $v$ tisočih dinarjev.

$\mathrm{Z}$ metodološkega stališča je zbrano gradivo $\mathrm{v}$ več pogledih vprašljivo. Pomisleke vzbujajo predvsem izpisi družbenega proizvoda po majhnih teritorialnih enotah, ne le po mestih, ampak še posebej po obmestnih naseljih. Odprto je ostalo vprašanje, kako razdeliti in komu dodeliti družbeni proizvod združenih podjetij, kot so npr. pošta ali železnica. Takratna metodologija zajemanja družbenega proizvoda je vrednotila predvsem proizvodnjo, le deloma pa je zajela tudi različne storitve, kar še posebej velja za storitve kvartarnega sektorja. Glede na to je bilo mogoče gradivo členiti le na tri skupine: na primarne, sekundarne in terciarne dejavnosti; $\mathrm{v}$ zadnjo so bile vključene tudi kvartarne dejavnosti. Nekatere pomisleke je npr. vzbujala lokacijska 
opredelitev primarnih dejavnosti: $\mathrm{v}$ mnogih primerih so jo pripisali mestom, kjer so bili sedeži velikih kmetijskih posestev in agroživilskih kombinatov. Zaradi tega se je $\mathrm{v}$ nekaterih slovenskih mestih pojavil primarni sektor z zelo visokim odstotkom (Ptuj, Murska Sobota, Radlje, Kočevje), kar ni smiselno, saj kmetijstvo in gozdarstvo nista urbani dejavnosti. Končno, ne kaže spregledati, da je bilo l. 1990 glede na gospodarsko in politično krizo takratne Jugoslavije dokaj nenormalno in da so tudi izračunani podatki bržkone spačeni, saj je bila takrat vrsta podjetij $\mathrm{v}$ težkih razmerah. Te pomanjkljivosti in metodološke napake moramo upoštevati pri vrednotenju rezultatov. Zato cenimo izsledke razprave le kot verjetne, nikakor pa ne kot dokončno ovrednotenje gospodarskih razmer.

Prostorske enote. Poseben problem je bila opredelitev mest. Do 1. 1994 Slovenija uradno ni imela mest, saj so ta pravni pojem opustili $\mathrm{v}$ šestdesetih letih po uvedbi komunalnega sistema. Ker je vendarle obstajala potreba po določitvi mest, je takšno opredelitev izdelal republiški zavod za statistiko pod pojmom "mestna naselja" (Zavod za statistiko, 1991, 1994). V spisek so vključili vsa večja naselja, ki so bila v preteklosti že priznana kot mesta, njim so dodali še občinska središča in nekatera mestom bližnja urbanizirana naselja ter večje turistične kraje. Spisek so občasno spreminjali glede na upravne spremembe ali večanje urbanizacije $v$ obmestjih. Opredelitev mest pa so dodatno zapletle nekatere upravne vključitve obmestnih naselij, ki so jih izvedle občinske oblasti. Tako so npr. v osemdesetih letih inkorporirali v mesta okoliška urbanizirana naselja v Ljubljani, Celju, Kopru, Novem mestu, ne pa npr. v Mariboru, Kranju, Novi Gorici ali Ptuju. Posledice se v naši analizi občutijo predvsem pri velikostni kategorizaciji mest ter $\mathrm{v}$ nuji, da smo tudi drugim mestom prišteli bližnja mestna naselja ter jih tako vsaj deloma izenačili (Vrišer, 1994). Zaradi teh razlik smo podatke podali na dva načina: seznam A obsega zgolj mesta brez okoliških naselij ( $v$ ilustracijo: $v$ primeru Nove Gorice niso vključeni Kromberk, Pristava, Rožna Dolina in Solkan), seznam B. pa v mestni obseg vključuje tudi okoliška mestna naselja, ki jih navaja statistični seznam. Iz strokovnih vidikov je B seznam nedvomno pravilnejši in daje bolj smiselne podatke. Vendar pa kaže upoštevati, da je opredelitev mest tudi v varianti B kompromis. Praviloma bi morali preveriti vsa mestom bližnja mestna naselja in ne le tista, ki jih je izločila statistična služba.

Seznam "mestnih naselij" smo spremenili še $v$ enem pogledu: iz njega smo izpustili osem krajev, ki so šteli ob zadnjem popisu manj kot 2000 prebivalcev (Čatež, Vipava, Kranjska Gora, Brestanica), pa čeprav so bila občinska središča (Mozirje, Pesnica, Šmarje pri Jelšah), ali so jih občasno smatrali za mesta (Bovec). Glede na kriterij 2000 prebivalcev pa smo v seznam uvrstili Črno, Muto, Radeče in Radence. Na ta način je seznam obsegal 73 krajev, med njimi 58 pravih mest in 15 mestnih (urbaniziranih) naselij. 
Obdelava podatkov. Zbrane podatke o družbenem proizvodu smo obdelali na tri načine. Najpreje smo jih razdelali glede na velikostne kategorije mest. Ločili smo pet skupin: v prvo smo uvrstili Ljubljano in Maribor, v drugo srednje velika mesta, ki so imela 1. 1991 ob popisu prebivalstva med 20.000 in 100.000 prebivalcev, skupino malih mest pa smo razdelili na tista $\mathrm{z} 10.000-20.000$ prebivalci, $\mathrm{s} 5.000-10.000$ in $\mathrm{z}$ 2.000-5.000 prebivalci.

Zaradi sprememb, ki jih je povzročila "priključitev" obmestnih urbaniziranih naselij k nekaterim mestom, so nastale razlike $v$ velikostni kategorizaciji mest. Tako sta se po B seznamu uvrstili v kategorijo 20.000 do 100.000 prebivalcev poleg Celja, Kopra, Kranja, Novega mesta in Velenja tudi Jesenice in Nova Gorica. V kategorijo 10.00020.000 prebivalcev pa se je poleg Domžal, Izole, Murske Sobote, Ptuja, Škofje Loke in Trbovelj vključil še Kamnik. V kategorijo s $5.000-10.000$ prebivalci pa sta z navedenimi inkorporacijami prišla tudi Tržič in Medvode.

Pri obdelavi smo proučili tudi odnos med ustvarjenim družbenim proizvodom in mestnim prebivalstvom. Uporabili smo končne podatke popisa prebivalstva 1.1991 in takratno upravno ureditev po naseljih (Zavod za statistiko, 1994).

Zbrano gradivo je omogočalo razčlenitev družbenega proizvoda po skupinah dejavnosti. V skupino primarnih dejavnosti smo uvrstili družbeni proizvod, ki je bil ustvarjen v kmetijstvu, gozdarstvu in vodnem gospodarstvu. V skupino sekundarnih dejavnosti smo šteli družbeni proizvod ustvarjen $v$ industriji $z$ rudarstvom, gradbeništvu ter obrti in osebnih storitvah. Poslednje sicer niso sodile med proizvodne panoge, vendar jih ni bilo moč izločiti iz obrti. Ker je $\mathrm{v}$ tej panogi vendarle proizvodna obrt največ ustvarila, smo jo uvrstili med sekundarne dejavnosti. Vse ostale panoge so tvorile terciarne dejavnosti, med njimi tudi kvartarne dejavnosti, ki pa niso veliko prispevale $\mathrm{k}$ družbenemu proizvodu.

Izsledki. Iz podatkov je razvidno, da so $1.1990 \mathrm{v}$ mestih ustvarili $\mathbf{7 7 . 0 7 \%}$ (varianta A) oziroma $80.3 \%$ (varianta B) vsega družbenega proizvoda Republike Slovenije v letu 1990 (glej tabelo 1). Na preostale kraje na podeželju je prišlo le $22.92 \%$ oziroma $19.68 \%$ družbenega proizvoda. Ta razporeditev je bila v znatnem razhajanju $\mathrm{z}$ razmestitvijo prebivalstva. Le-tega je bilo $\mathrm{v}$ mestih in mestnih naseljih $46.41 \%$ (varianta A) oziroma 50.37\% (varianta B). Očitno je bila urbanizacijska stopnja $\mathrm{v}$ gospodarstvu znatno večja kot pa pri prebivalstvu. Koncentracija družbenega proizvoda $v$ mestih je potrjevala že večkrat izraženo misel, da je Slovenija glede na svojo stopnjo razvitosti populacijsko premalo urbanizirana in da izkazuje nekakšno hipourbaniziranost, ki jo drugod, v podobnih družbenoekonomskih razmerah, ne poznajo. Rezultati celo kažejo, da se stopnja urbanizacije, ki jo večidel merimo z deležem mestnega prebivalstva, $v$ zadnjih desetletjih ne povečuje in da $v$ poselitvi še vedno prevladujejo suburbanizacijske težnje, ko veliko slovenskega prebivalstva daje 
večjo prednost bivanju $\mathrm{v}$ obmestju ali $\mathrm{v}$ predmestjih kot pa nastanitvi $\mathrm{v}$ mestnih središčih.

Druga temeljna ugotovitev se nanaša na razporeditev ustvarjenega družbenega proizvoda po velikostnih kategorijah mest. Na obe veliki mesti je prišlo okoli $30 \%$ družbenega proizvoda, na srednje velika mesta (20.000-100.000 prebivalcev) $15-18 \%$, na številčno veliko skupino malih mest (2000-20.000 prebivalcev) pa okoli $31 \%$. Tudi tu je bilo razhajanje glede na razporeditev prebivalstva znatno, vendar večje v primeru velikih mest, kjer je bilo razmerje $30 \%$ DP napram $18,86 \%$ (varianta A) oziroma $20.10 \%$ (varianta B) prebivalstva, nekoliko manjše pri srednje velikih

Tabela 1. Prebivalstvo (1. 1991) in družbeni proizvod v slovenskih mestih (1. 1990) Population (1991) and gross domestic product (1990) in Slovenian towns and cities

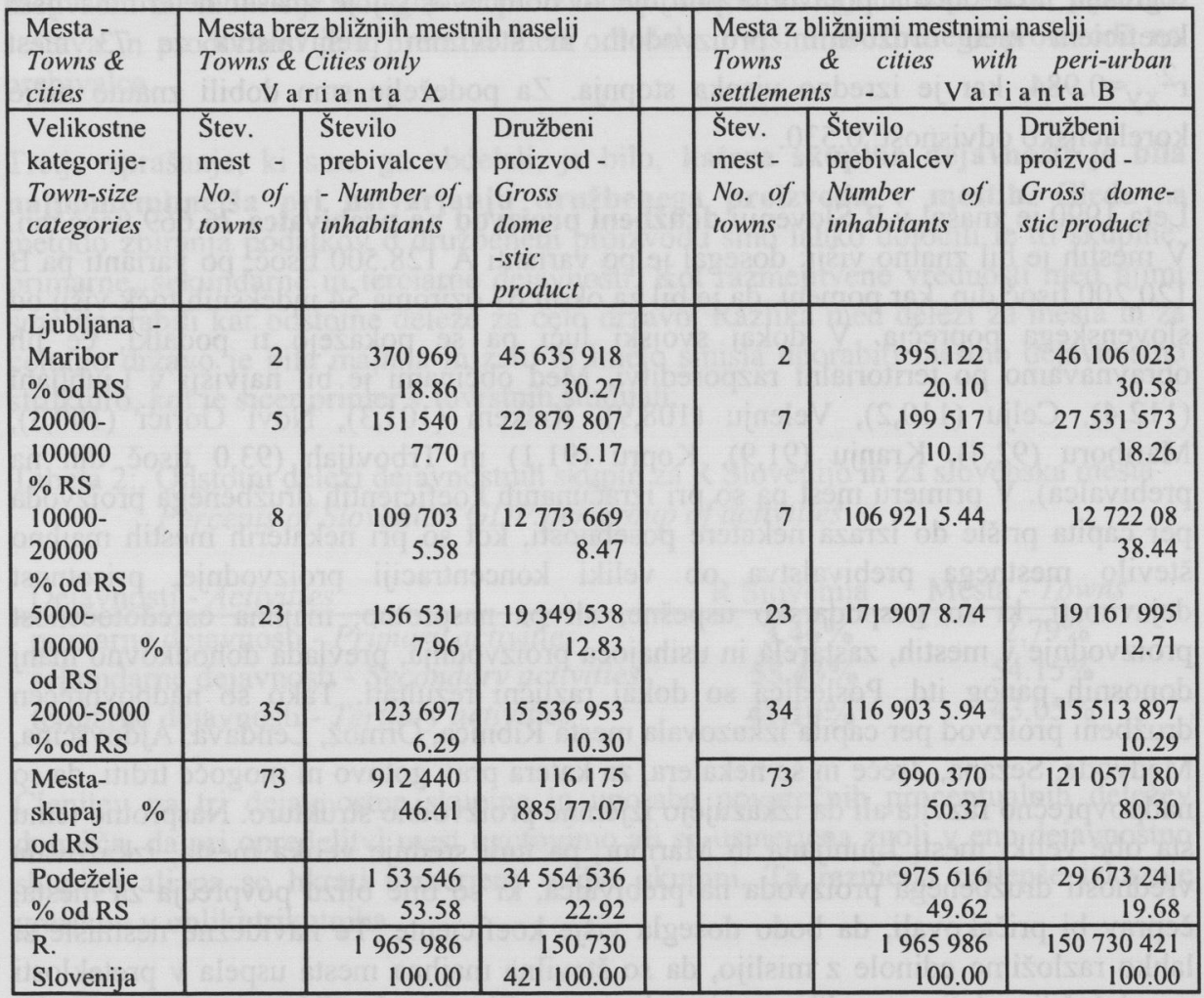


mestih (15-18\% DP napram 7.70\% oziroma 10.15\%) in občutno pri malih mestih (31\% DP napram $19.8 \%$ oziroma $20.1 \%$ prebivalstva). Iz tega bi lahko sklepali, da sta: 1.) oba pojava, prebivalstvo in družbeni proizvod, $v$ določeni medsebojni odvisnosti in 2.) da obstajajo pri ustvarjanju družbenega proizvoda v Sloveniji ne le regionalne razlike, ampak tudi razlike med mesti in podeželjem ter med samimi mesti. Opisano dihotomijo bi lahko pripisali dvema razlogoma: prvemu, da je delitev dela v večjih mestih na višji ravni in da se $\mathrm{z}$ njo ustvari več družbenega proizvoda. Bolj verjetna pa je druga razlaga, da $\mathrm{v}$ večjih mestnih naselbinah dela zelo veliko zaposlenih iz okolice, njihov delovni učinek pa gre v korist mest. V Sloveniji, kjer je te delovne migracije zelo veliko, je bržkone treba predvsem tu iskati razlog za te razlike.

Glede odnosa med ustvarjenim družbenim proizvodom in prebivalstvom je iz podatkov razvidno, da je obstajala dokaj tesna soodvisnost. Izračunana linearna regresija med obema pojavoma potrjuje to domnevo, saj je znašal determinacijski koeficient med družbenim proizvodom in številom prebivalstva za 73 mest $\mathrm{r}^{2} \mathrm{xy}=0.984$, kar je izredno visoka stopnja. Za podeželje smo dobili znatno nižjo korelacijsko odvisnost: 0.530 .

Leta 1990 je znašal v R Sloveniji družbeni proizvod na prebivalca 76.669 tisoč din. $\mathrm{V}$ mestih je bil znatno višji: dosegal je po varianti A 128.500 tisoč, po varianti pa B 120.200 tisoč din, kar pomeni, da je bil za okoli 67 oziroma 54 indeksnih točk višji od slovenskega poprečja. V dokaj svojski luči pa se pokažejo ti podatki, če jih obravnavamo po teritorialni razporeditvi. Med občinami je bil najvišji $v$ Ljubljani $(112,4)$, Celju $(110,2)$, Velenju $(108,9)$, Krškem $(101,3)$, Novi Gorici $(100,3)$, Mariboru $(92,4)$, Kranju $(91,9)$, Kopru $(91,1)$ in Trbovljah $(93,0$ tisoč din na prebivalca). V primeru mest pa so pri izračunanih koeficientih družbenega proizvoda per capita prišle do izraza nekatere posebnosti, kot so pri nekaterih mestih majhno število mestnega prebivalstva ob veliki koncentraciji proizvodnje, prisotnost dejavnosti, ki so gospodarsko uspešne, ali pa nasprotno, majhna osredotočenost proizvodnje $v$ mestih, zastarela in usihajoča proizvodnja, prevlada dohodkovno manj donosnih panog itd. Posledica so dokaj različni rezultati. Tako so nadpovprečen družbeni proizvod per capita izkazovala mesta Ribnica, Ormož, Lendava, Ajdovščina, Medvode, Sežana, Zreče in še nekatera, za katera prav gotovo ni mogoče trditi, da so nadpovprečno razvita ali da izkazujejo izjemno proizvodno strukturo. Nasprotno temu sta obe veliki mesti Ljubljana in Maribor, pa tudi srednje velika mesta, izkazovala vrednosti družbenega proizvoda na prebivalca, ki so bile blizu povprečja za mesta, čeprav bi pričakovali, da bodo dosegla višje koeficiente. Te navidezne nesmisle si lahko razložimo edinole $\mathrm{z}$ mislijo, da so številna majhna mesta uspela $\mathrm{v}$ preteklosti osredotočiti relativno velike proizvodne zmogljivosti ob šibkem večanju števila prebivalstva in so obenem gradila svojo prosperiteto na račun dnevnih migrantov, ki so hodili v te centre na delo (Ribnica, Ajdovščina, Ormož, Medvode, Lendava). V nekaterih primerih se je ta uspešnost opirala na trgovino (Sežana), na izjemni in 
uspešni položaj določene dejavnosti (Krško, Zreče, Šoštanj), ali pa na monopolni položaj v pretežno agrarni okolici brez konkurenčnih centrov (Murska Sobota, Ptuj, Lendava). Nižje številke beležimo prav $v$ primeru mest, kjer se je $\mathrm{z}$ urbanizacijo izvršila tudi decentralizacija proizvodnih kapacitet (Domžale, Radovljica, Dravograd). Pri mnogih mestih je bil nizek družbeni proizvod na prebivalca posledica usihajoče ali vsaj stagnantne industrije oziroma rudarstva (Trbovlje, Jesenice, Hrastnik, Izola, Mežica, Idrija).

Mesta so dosegala znatno večji socialni produkt na prebivalca kot pa okoliško podeželje. Razmerje med družbenim proizvodom na mestnega prebivalca in družbenim proizvodom na podeželskega prebivalca je bilo na manj razvitih območjih nekajkrat višje kot $\mathrm{v}$ razvitih občinah ( $\mathrm{v}$ murskosoboški občini npr. 1:15, ljutomerski 1:19, lenarški 1:11; v Ljubljani pa je bila nasprotno razlika 1:4,8, v kranjski občini 1:3,0, koprski 1:4,6 itd.). Pri večini slovenskih mest je bila prosperiteta odvisna predvsem od industrije kot glavne proizvodne dejavnosti. Njena uspešnost, panožna sestava in prodornost je $\mathrm{v}$ pretežni meri odločala o višini družbenega proizvoda na prebivalca.

Tretje vprašanje, ki smo ga obdelali, je bilo, katera skupina dejavnosti je bila najpomembnejša pri ustvarjanju družbenega proizvoda v mestih. Glede na metodo zbiranja podatkov o družbenem proizvodu smo lahko določili le tri skupine: primarne, sekundarne in terciarne dejavnosti. Kot razmejitvene vrednosti med njimi smo uporabili kar odstotne deleže za celo državo. Razlika med deleži za mesta in za celotno državo je bila majhna in zato ni imelo smisla uporabiti mestno dejavnostno strukturo, kot je sicer primer v tovrstnih študijah:

Tabela 2:. Odstotni deleži dejavnostnih skupin za R Slovenijo in za slovenska mesta Percents of Slovenian GDP per group of activities

\begin{tabular}{lcc} 
Dejavnosti - Activities & R Slovenija & Mesta - Towns \\
\hline primarne dejavnosti - Primary activities & $\mathbf{3 . 4 6 \%}$ & $2,79 \%$ \\
sekundarne dejavnosti - Secondary activities & $\mathbf{5 5 . 4 3 \%}$ & $54.15 \%$ \\
terciarne dejavnosti - Tertiary activities & $\mathbf{4 1 . 1 0 \%}$ & $43.05 \%$
\end{tabular}

Členitev na tri dejavnostne skupine in uporaba povprečnih procentualnih deležev dopušča, da pri opredelitvi mest ugotovimo ali so usmerjena zgolj v eno dejavnostno skupino ali pa so hkrati usmerjena $\mathrm{v}$ dve skupini. Ta razmerja najlepše izkazuje grafikon v obliki trikotnika. 


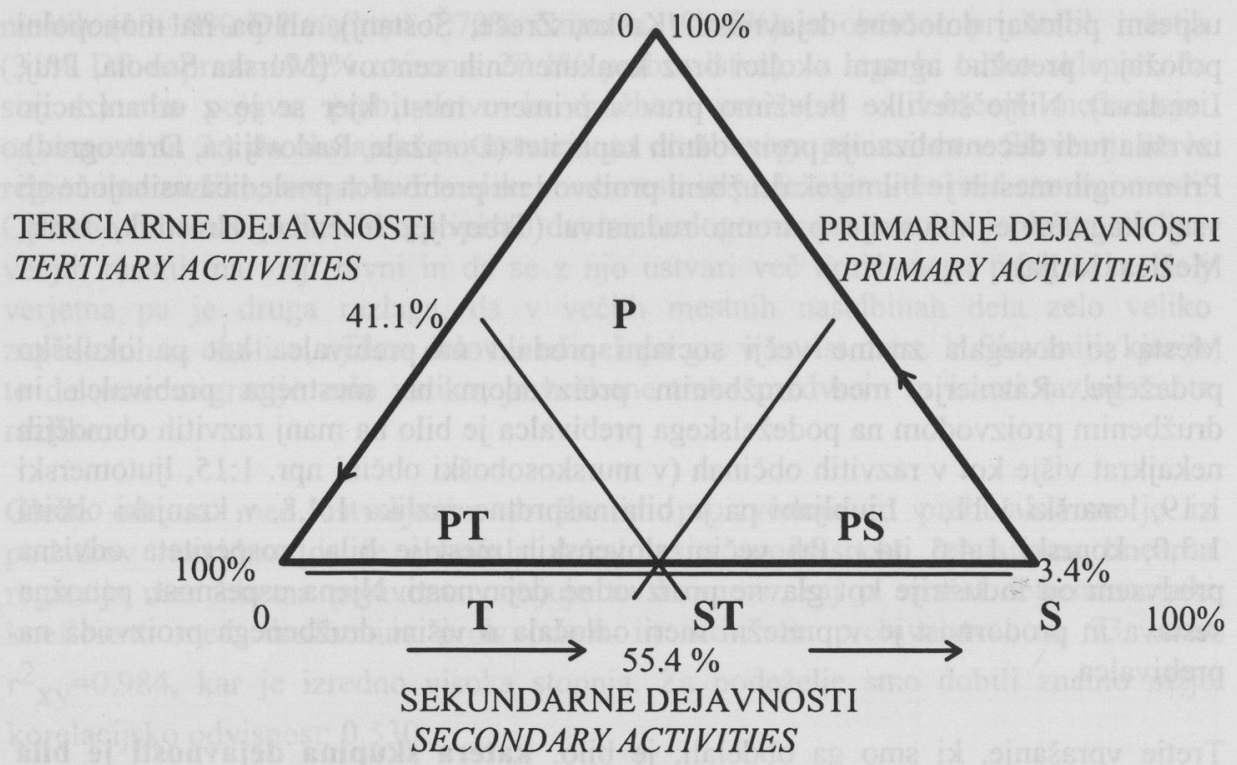

$\mathrm{P}=$ primarne dejavnosti - primary activities

$\mathrm{S}=$ sekundarne dejavnosti - secondary activities

$\mathrm{T}=$ terciarne dejavnosti - tertiary activities

$\mathrm{PS}=$ primarno-sekundarne dejavnosti - primary-secondary activities

$\mathrm{PT}=$ primarno-terciarne dejavnosti - primary-tertiary activities

$\mathrm{ST}=$ sekundarno-terciarne dejavnosti - secondary-tertiary activities

Za slovenska mesta lahko rečemo, da so glede na ustvarjeni družbeni proizvod, izrazito sekundarno usmerjena. Kot nekakšna posebnost nastopa pa tudi nekaj mest s primarno orientacijo. Razmeroma slabo so zastopana terciarno usmerjena mesta. To je nedvomno anomalija, saj so mesta $v$ tržnih gospodarstvih prvenstveno usmerjena $v$ storitvene dejavnosti. Pripišemo jo lahko omejenemu pomenu trga $v$ socialistični družbeni ureditvi in pretirani industrializaciji, ki se je izvajala vso povojno dobo. Sestava slovenskih mest je bila glede na strukturo ustvarjenega družbenega proizvoda naslednja: 
Tabela 3. Dejavnostna usmeritev slovenskih mest glede na ustvarjeni družbeni proizvod

Activity orientation of Slovenian towns as to the produced GDP

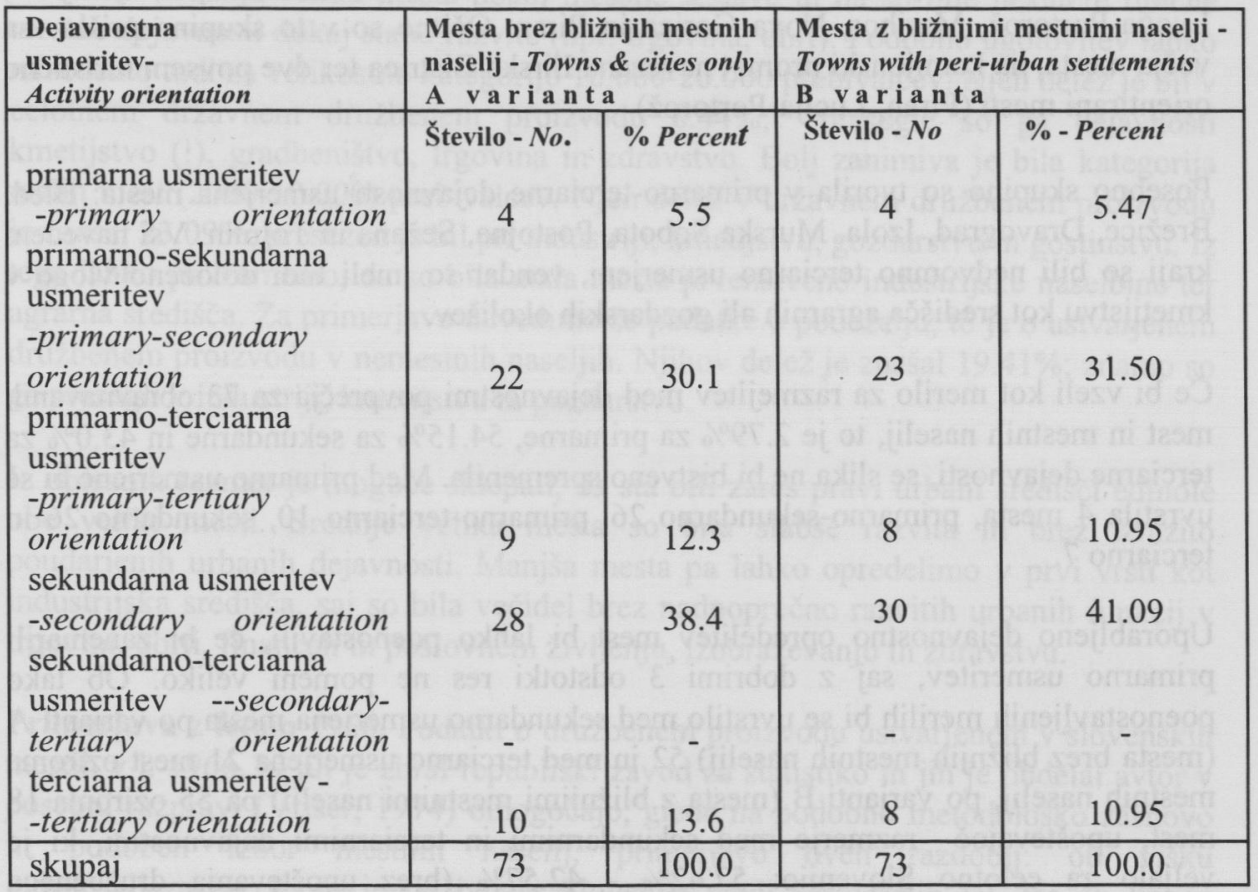

Primarno usmerjena so bila mesta: Črna, Kočevje, Ptuj in Radlje. To usmerjenost je treba verjetno pripisati dejstvu, da so tu bili sedeži večjih kmetijskih podjetij.

V sekundarne dejavnosti so bila usmerjena mesta: Ajdovščina, Domžale, Grosuplje, Hrastnik, Jesenice, Kamnik, Kranj, Lenart, Lendava, Litija, Ljutomer, Medvode, Mengeš, Metlika, Mežica, Muta, Radeče, Radenci, Radovljica, Ravne, Rogaška Slatina, Slovenske Konjice, Tržič, Škofja Loka, Trbovlje, Velenje, Vrhnika, Zagorje, Zreče, Železniki. Tudi pri tej uvrstitvi je več pomislekov. Taki primeri so Rogaška Slatina, Grosuplje, Lenart, Ljutomer, Radenci, Radovljica ali Domžale, za katere bi pričakovali ali pretežno terciarno ali vsaj sekundarno-terciarno usmeritev.

Dokaj številna je bila primarno-sekundarna usmeritev; v njo so sodila mesta: Cerknica, Črnomelj, Gornja Radgona, Idrija, Krško, Laško, Logatec, Novo mesto, Ormož, Pivka, Prevalje, Ribnica, Ruše, Senovo, Sevnica, Slovenj Gradec, Slovenska Bistrica, Šempeter, Šentjur, Šoštanj, Trebnje, Žalec, Žiri. V skupini so bila mesta, ki 
bi jim ne pripisali večjega pomena na področju primarnih dejavnosti (npr. Slovenj Gradec, Idrija, Laško, Senovo itd.)

Med terciarno usmerjena mesta so se uvrstila: Celje, Ilirska Bistrica, Koper, Ljubljana, Lucija-Portorož, Maribor, Nova Gorica in Piran. Očitno so v to skupino prišla vsa večja mesta, na kamijonski promet navezana Ilirska Bistrica ter dve povsem turistično orientirani mesti (Piran, Lucija-Portorož)

Posebno skupino so tvorila v primarno-terciarne dejavnosti usmerjena mesta: Bled, Brežice, Dravograd, Izola, Murska Sobota, Postojna, Sežana in Tolmin. Vsi navedeni kraji so bili nedvomno terciarno usmerjeni, vendar so imeli tudi določeno vlogo $\mathrm{v}$ kmetijstvu kot središča agrarnih ali gozdarskih okolišev.

Če bi vzeli kot merilo za razmejitev med dejavnostmi povprečja za 73 obravnavanih mest in mestnih naselij, to je $2.79 \%$ za primarne, $54.15 \%$ za sekundarne in $43.0 \%$ za terciarne dejavnosti, se slika ne bi bistveno spremenila. Med primarno usmerjene bi se uvrstila 4 mesta, primarno-sekundarno 26, primarno-terciarno 10, sekundarno 26 in terciarno 7.

Uporabljeno dejavnostno opredelitev mest bi lahko poenostavili, če bi zanemarili primarno usmeritev, saj $\mathrm{z}$ dobrimi 3 odstotki res ne pomeni veliko. $\mathrm{Ob}$ tako poenostavljenih merilih bi se uvrstilo med sekundarno usmerjena mesta po varianti A (mesta brez bližnjih mestnih naselij) 52 in med terciarno usmerjena 21 mest oziroma mestnih naselij, po varianti B (mesta z bližnjimi mestnimi naselji) pa 55 oziroma 18 mest, upoštevajoč razmerje med sekundarnimi in terciarnimi dejavnostmi, ki je veljalo za celotno Slovenijo: $57.42 \%-42.57 \%$ (brez upoštevanja družbenega proizvoda primarnih dejavnosti).

Kakšna je bila koncentracija dejavnosti v mestih? Primerjava med družbenim proizvodom ustvarjenim $\mathrm{v}$ državi in tistim, ki je bil proizveden $\mathrm{v}$ mestih po posameznih panogah, pokaže, da so bile najbolj urbane dejavnosti: stanovanjskokomunalna dejavnost, izobraževanje in kultura, finance in druge poslovne dejavnosti ter gradbeništvo, saj je znašal- mestni delež preko $90 \%$. Nekaj manj, $80-90 \%$ od celotnega državnega družbenega proizvoda, sta ustvarili v mestih trgovina in obrt. Industrija $\mathrm{v}$ mestih je proizvedla $76.8 \%$ od celotnega industrijskega družbenega proizvoda, kar potrjuje tezo, da industrija vendarle ni prava urbana panoga.

Glede na velikostne kategorije mest so bile $\mathrm{v}$ obeh mestih $\mathrm{z}$ več kot 100.000 prebivalci osredotočene naslednje dejavnosti: gradbeništvo, trgovina, gostinstvo, obrt, stanovanjsko in komunalno gospodarstvo ter še posebej finance in izobraževanje ter kultura. Njihov delež je znatno presegal $30.81 \%$, kolikor je od celotnega $v$ državi ustvarjenega družbenega proizvoda odpadlo na ti dve mesti. Kategorija mest z 20.000100.000 prebivalci, ki je bila udeležena $\mathrm{z} 18.25 \%$ pri ustvarjenem družbenem 
proizvodu $v$ državi, je imela nadpovprečen delež $v$ stanovanjskem in komunalnem gospodarstvu ter poslovnem življenju; navedeni povprečni delež pa so presegale tudi dejavnosti: gradbeništvo, promet ter zdravstvo. Iz tega lahko razberemo, da so bila slovenska srednje velika mesta dokaj mešane sestave in da so bile nekatere tipične mestne dejavnosti dokaj slabo razvite (npr. trgovina, obrt). Podobno ugotovitev lahko navedemo tudi za velikostno kategorijo $10.000-20.000$ prebivalcev. Njen delež je bil v celotnem državnem družbenem proizvodu $8.44 \%$; presegle so ga dejavnosti kmetijstvo (!), gradbeništvo, trgovina in zdravstvo. Bolj zanimiva je bila kategorija malih mest $(2000-10.000)$ prebivalcev. Njen delež $v$ državnem družbenem proizvodu je znašal 23.09\%, presežen je bil pri industriji, kmetijstvu, gozdarstvu in gostinstvu. Iz tega lahko povzamemo, da so bila mala mesta prvenstveno industrijske naselbine ter agrarna središča. Za primerjavo navedimo še podatke o podeželju, to je o ustvarjenem družbenem proizvodu v nemestnih naseljih. Njihov delež je znašal $19.41 \%$; znatno so ga presegli v industriji, kmetijstvu in gozdarstvu.

Iz opisanih razmer je mogoče sklepati, da sta bili zares pravi urbani središči edinole obe veliki mesti. Srednje velika mesta so bila slabše razvita in brez izrazito poudarjenih urbanih dejavnosti. Manjša mesta pa lahko opredelimo v prvi vrsti kot industrijska središča, saj so bila večidel brez nadpoprečno razvitih urbanih funkcij v trgovini, obrti, financah in poslovnem življenju, izobraževanju in zdravstvu.

Primerjava $\mathrm{z}$ letom 1966. Podatki o družbenem proizvodu ustvarjenem v slovenskih mestih v l. 1966, ki jih je zbral republiški zavod za statistiko in jih je obdelal avtor v posebni razpravi (Vrišer, 1974) omogočajo, glede na podobno metodološko zasnovo in podoben izbor mestnih naselij, primerjavo dveh razdobij: ob višku industrialiazacije, ki jo je doživljala Slovenija sredi šestdesetih let, ter ob koncu socialističnega obdobja. Primerjava pokaže, da se je delež urbanih središč v ustvarjenem družbenem proizvodu $\mathrm{v}$ teh petindvajsetih letih še povečal in sicer od $76.0 \%$ na $80.3 \%$. Obenem je prišlo do preporazdeditve deležev med velikostnimi kategorijami mest. Obe veliki mesti, Ljubljana in Maribor, sta zadržali svoj $30 \%$ delež. Znatno se je povečal delež srednje velikih mest, od $7.3 \%$ na $18.26 \%$, kar je mogoče pripisati rasti, pa tudi določeni krepitvi njihovega pomena. Nasprotno temu se je delež malih mest znižal od $37.8 \%$ na $31.43 \%$. Upad je zlasti očiten v kategoriji mest z 2000-5000 prebivalcev, na katero je sprva odpadlo $18.5 \%$, sedaj pa le še $10.29 \%$. 
Tabela 4.: Delež mest v ustvarjenem družbenem proizvodu države po dejavnosti 1. 1990 v 000 din

Percentages of Slovenian GDP produced in towns by individual activities in 1990 (in 000 of dinars)

\begin{tabular}{|c|c|c|c|}
\hline $\begin{array}{l}\text { Dejavnosti } \\
\text { Activities }\end{array}$ & $\begin{array}{l}\text { Družbeni proizvod } \\
\text { Slovenije - } \\
\text { GDP of Slovenia }\end{array}$ & $\begin{array}{c}\text { Družbeni proizvod } 73 \\
\text { mest } \mathrm{z} \text { bližnjimi naselji } \\
\text { GDP of } 73 \text { towns }\end{array}$ & $\begin{array}{l}\text { \% DP ustvarjenega } \\
\mathrm{v} \text { mestih - Percen } \\
\text { tages of GDP } \\
\text { produced in towns }\end{array}$ \\
\hline Skupaj - Total & 150730421 & 121479101 & 80.59 \\
\hline Industrija- Manufacturing & 72685088 & 55851552 & 76.84 \\
\hline Kmetijstvo- Agriculture & 3353957 & 2024818 & 60.37 \\
\hline Gozdarstvo- Forestry & 1556149 & 1052602 & 67.64 \\
\hline $\begin{array}{l}\text { Vodno gospodarstvo- Water } \\
\text { management }\end{array}$ & 302974 & 302974 & 100.00 \\
\hline Gradbeništvo- Construction & 6926181 & 6535785 & 94.36 \\
\hline Promet in zveze- Transport & 10288299 & 8143873 & 79.16 \\
\hline Trgovina - Trade & 33629135 & 27814445 & 82.70 \\
\hline Gostinstvo-turizem & 4718753 & 3718660 & 78.80 \\
\hline Catering \& tourism & & & \\
\hline $\begin{array}{l}\text { Obrt-osebne storitve - Craft } \\
\text { \& private services }\end{array}$ & 3951388 & 3433162 & 86.88 \\
\hline $\begin{array}{l}\text { Stanovanjs. komunalne } \\
\text { dejavnosti } \\
\text { Housing \& public utilities }\end{array}$ & 2838333 & 2737958 & 96.46 \\
\hline Finance-poslovne dejavnosti & 7971995 & 7594299 & 95.50 \\
\hline $\begin{array}{l}\text { Finacial \& business } \\
\text { activities }\end{array}$ & & & \\
\hline $\begin{array}{l}\text { Izobraževanje-kultura - } \\
\text { education \& culture }\end{array}$ & 1631489 & 1569537 & 95.96 \\
\hline Zdravstvo-socialno varstvo - & 876680 & 699436 & 79.78 \\
\hline $\begin{array}{l}\text { Medical care \& social } \\
\text { security }\end{array}$ & & & \\
\hline
\end{tabular}


Tabela 5.: Primerjava ustvarjenega družbenega proizvoda v slovenskih mesti 1966 in 1990 v 000 din

The comparison between the GDPs produced in Slovenian towns in 1966 and 1990 in 000 din

\begin{tabular}{|c|c|c|c|c|c|c|}
\hline $\begin{array}{c}\text { Mesta } \\
\text { Towns \& } \\
\text { cities }\end{array}$ & 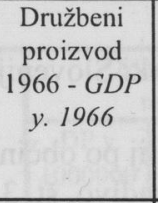 & $\begin{array}{c}\text { Družbeni } \\
\text { proizvod l. } \\
1990-G D P y \\
1990\end{array}$ & $\begin{array}{c}\text { \% družbene- } \\
\text { ga proizvoda } \\
1.1966- \\
\text { Percent of } \\
\text { GDP in year } \\
1966\end{array}$ & $\begin{array}{c}\text { \% družbenega } \\
\text { proizvoda } 1 . \\
1990 \text { - Percent } \\
\text { of GDP in year } \\
1990\end{array}$ & $\begin{array}{c}\% \text { mestnega } \\
\text { prebivalstva } 1 . \\
1966 \text {-Percent } \\
\text { of urban } \\
\text { population } \\
1966\end{array}$ & $\begin{array}{c}\text { \% mestnega } \\
\text { prebivalstva } 1 . \\
1990 \text {-Percent } \\
\text { of urban } \\
\text { population } \\
1990 \\
\end{array}$ \\
\hline Slovenija & 14350437 & 150730421 & 100.0 & 100.0 & 100.0 & 100.0 \\
\hline $\begin{array}{l}\text { Mesta- } \\
\text { Towns }\end{array}$ & 10906869 & 121057180 & 76.0 & 80.3 & 42.8 & 50.4 \\
\hline$>100.000$ & 4428948 & 46106023 & 30.8 & 30.6 & 19.0 & 20.1 \\
\hline $\begin{array}{l}20000- \\
100000\end{array}$ & 1045535 & 27521573 & 7.3 & 18.3 & 3.6 & 10.1 \\
\hline $\begin{array}{l}10000- \\
19999\end{array}$ & 1483155 & 12722083 & 10.4 & 8.4 & 5.3 & 5.4 \\
\hline $\begin{array}{l}5.000- \\
9.999\end{array}$ & 1936698 & 19161995 & 13.5 & 12.7 & 7.5 & 8.7 \\
\hline$<5.000$ & 2003533 & 15513897 & 13.8 & 10.3 & 7.0 & 5.9 \\
\hline
\end{tabular}

Opisani razvoj dovoljuje sklep, da se je urbanizacija $v$ Sloveniji $v$ tem petindvajsetletnem obdobju nekoliko povečala in je potekala $v$ korist večjih urbanih naselij. K temu je nekaj prispevala obča prerazmestitev prebivalstva: nadaljevanje migracij s podeželja $v$ mesta, populacijska rast večjih mest, še posebej tistih $\mathrm{z}$ več kot 20.000 prebivalci, ter uvedba komunalnega sistema, ki je dajal prednost občinskim središčem napram ruralnemu podeželju. Vendar je na preporazdelitev družbenega proizvoda nedvomno vplivala tudi rast proizvodnih zmogljivosti in storilnosti, ki je bila izrazitejša in uspešnejša $v$ večjih mestih.

Do določenih sprememb je prišlo tudi glede osredotočenosti nekaterih dejavnosti $v$ mestih. L. 1966 so bile najbolj "mestne" stanovanjske in komunalne dejavnosti $(100 \%)$, promet $(97.1 \%)$, trgovina $(94.1 \%)$ in gradbeništvo $(90.1 \%), 1.1990$ so to bile stanovanjsko-komunalne dejavnosti $(96.5 \%)$, finance in poslovne dejavnosti $(95.3 \%)$, gradbeništvo $(94.4 \%)$ ter obrt in storitve $(86.9 \%)$. Zmanjšala pa se je koncentracija prometa (na 79.2\%), trgovine (na $82.7 \%$ ) in industrije (od $85.5 \%$ na $76.8 \%$ ) v mestih. $\mathrm{K}$ zmanjševanju osredotočenosti dejavnosti $\mathrm{v}$ mestih je verjetno veliko prispeval obči dvig življenjskega standarda na podeželju, postopna decentralizacija, ki je spodbujala razvoj manjših podeželskih središč, ter politika skladnejšega regionalnega razvoja, ki je blažila pretirane razlike med bolj in manj razvitimi. 


\section{VIRI IN LITERATURA}

- Vrišer I.; 1974: Mesta in urbano omrežje v SR Sloveniji, Značilnosti njihovega razvoja in družbeno gospodarskega pomena s posebnim ozirom na mala mesta. Geografski zbornik, XIV/3, Ljubljana.

- Vrišer I., 1994: Opredelitev mest in mestnih občin v Republiki Sloveniji. Državni zbor Republike Slovenije. Ljubljana. (Razmnoženo).

- Zavod Republike Slovenije za statistiko, 1991: Pregled naselij po občinah Republike Slovenije in pregled občin SFRJ. Metodološko gradivo, št. 3/91. Ljubljana.

- Zavod Republike Slovenije za statistiko: Družbeni proizvod po mestnih naseljih in področjih dejavnosti za leto $1990 \mathrm{v}$ tisoč din. Ljubljana, 1994

- Zavod Republike Slovenije za statistiko: Družbeni proizvod po podroćjih dejavnosti za leto $1990 \mathrm{v}$ tisoč din (po občinah). Ljubljana, 1994.

- Zavod Republike Slovenije za statistiko, 1994: 32. Pregled mestnih naselij., 32.1

- Prebivalstvo, gospodinjstva in stanovanja v mestnih naseljih ob popisu 1991. Statistični letopis Republike Slovenije. Ljubljana.

- Zavod Republike Slovenije za statistiko, 1994: Pregled po občinah, 33-3 Prebivalstvo ob popisih. Statistični letopis Republike Slovenije. Ljubljana. 
Priloga: Družbeni proizvod ustvarjen v mestih (1. 1990), mestno prebivalstvo (1. 1991), družbeni proizvod na prebivalca, delež v mestih ustvarjenega družbenega proizvoda od skupnega družbenega proizvoda občine in dejavnostna opredelitev mest glede na ustvarjeni družbeni proizvod

\begin{tabular}{|c|c|c|c|c|c|c|c|c|c|c|}
\hline \multirow[t]{2}{*}{ Mesta } & \multicolumn{4}{|c|}{$\begin{array}{l}\text { Mesta brez bližnjih } \\
\text { mestnih naselij }\end{array}$} & \multicolumn{4}{|c|}{$\begin{array}{l}\text { Mesta z bližnjimi } \\
\text { mestnimi naselji }\end{array}$} & \multirow{2}{*}{\begin{tabular}{|c|}
$\%$ v mestu \\
ustvarjene- \\
ga DP \\
od DP \\
v občini
\end{tabular}} & \multirow{2}{*}{$\begin{array}{l}\text { Dejav- } \\
\text { nostna } \\
\text { oprede- } \\
\text { litev }\end{array}$} \\
\hline & $\begin{array}{c}\text { DP v } \\
1000000 \\
\text { din } \\
\end{array}$ & \begin{tabular}{|c|} 
Stevilo \\
prebi- \\
valcev
\end{tabular} & \begin{tabular}{l|l} 
DP na \\
prebi- \\
valca
\end{tabular} & Rang & $\begin{array}{c}\text { DP v } \\
1000000 \\
\text { din }\end{array}$ & $\begin{array}{c}\text { Število } \\
\text { prebi- } \\
\text { valcev }\end{array}$ & $\begin{array}{l}\text { DP na } \\
\text { prebi- } \\
\text { valca }\end{array}$ & Rang & & \\
\hline Ajdovščina & 1412.5 & 6116 & 230.9 & 5 & 1413.2 & 6523 & 216.6 & 4 & 87.9 & $\bar{S}$ \\
\hline Bled & 630.5 & 5664 & 111.3 & 43 & 630.5 & 5665 & 111.3 & 38 & 32.2 & PT \\
\hline Brežice & 650.9 & 6856 & 94.9 & 54 & 650.9 & 6856 & 94.9 & 53 & 63.6 & PT \\
\hline Celje & 6319.8 & 40710 & 155.2 & 20 & 6319.8 & 40710 & 155.2 & 19 & 88.5 & $T$ \\
\hline Cerknica & 418.4 & 3445 & 121.4 & 35 & 418.4 & 3445 & 121.4 & 33 & 44.4 & PS \\
\hline Črna & \begin{tabular}{l|l}
48.2 \\
\end{tabular} & 2535 & 19 & 73 & \begin{tabular}{l|l}
48.2 \\
\end{tabular} & 2535 & 19 & 73 & 2.4 & $P$ \\
\hline Črnomelj & 435.7 & 5462 & 79.7 & 61 & 458.9 & 5817 & 78.9 & 62 & 58.5 & PS \\
\hline Domžale & 626.6 & 11023 & 56.8 & 65 & 1297.4 & 16011 & 81 & 60 & 47.9 & $T$ \\
\hline Dravograd & 178.8 & 3502 & 51 & 67 & 178.8 & 3502 & 51 & 67 & 33.4 & PT \\
\hline Gor. Radgona & 744.5 & 3778 & 197 & 10 & 744.5 & 3778 & 197 & 9 & 55.6 & PS \\
\hline Grosuplje & 496 & 5522 & 89.8 & 57 & 568.8 & 5602 & 101.5 & 48 & 51.6 & $\mathrm{~S}$ \\
\hline Hrastnik & 667.7 & 6673 & 100 & 51 & 667.7 & 6673 & 100 & 50 & 91.6 & S \\
\hline Idrija & 582.3 & 6171 & 94.3 & 55 & 582.3 & 6171 & 94.3 & 54 & 43.2 & PS \\
\hline Il. Bistrica & 635.9 & 4880 & 130.3 & 31 & 635.9 & 4880 & 130.3 & 26 & 69.4 & $T$ \\
\hline Izola & 860.8 & 10284 & \begin{tabular}{l|l}
83.7 \\
\end{tabular} & 59 & 877.2 & 12119 & 72.3 & 63 & 80.1 & PT \\
\hline Jesenice & 1309.9 & 18807 & 69.6 & 62 & 1372.2 & 21702 & 63.2 & 65 & 82.7 & $\mathrm{~S}$ \\
\hline Kamnik & 1718.3 & 9695 & 177.2 & 15 & 2030.2 & 12988 & 156.3 & 18 & 85.4 & $S$ \\
\hline Kočevje & 1098.9 & 9265 & 118.6 & 38 & 1102.9 & 9958 & 110.7 & 39 & 96.6 & $P$ \\
\hline Koper & 3503.5 & 24704 & 141.8 & 25 & 3503.5 & 24704 & 141.8 & 24 & 84.7 & $\mathrm{~S}$ \\
\hline Kranj & 5280.3 & 36456 & 144.8 & 24 & 5375.2 & 41978 & 128 & 27 & 80.7 & $S$ \\
\hline Krško & 1267.1 & 7085 & 178.8 & 14 & 1273.3 & 8033 & 158.5 & 17 & 43.7 & PS \\
\hline Laško & 489.5 & 3641 & 134.4 & 28 & 391.5 & 3641 & 107.5 & 42 & 43.3 & PS \\
\hline Lenart & 304.9 & 2531 & 120.4 & 36 & 304.9 & 2531 & 120.4 & 34 & 66.4 & $\mathrm{~S}$ \\
\hline \begin{tabular}{|l} 
Lendava \\
\end{tabular} & 944.5 & 3807 & 248.1 & 3 & 954 & 4571 & 208.7 & 7 & 71.3 & $\mathrm{~S}$ \\
\hline Litija & 326 & 6510 & 50 & 68 & 550.2 & 7900 & 69.6 & 64 & 69.6 & $\mathrm{~T}$ \\
\hline Ljubljana & 33622.5 & 267008 & 125.9 & 33 & 33767.3 & 270513 & 124.8 & 30 & 93.3 & $T$ \\
\hline Ljutomer & 557.9 & 3651 & 152.8 & 21 & 557.9 & 3651 & 152.8 & 21 & 82.5 & $S$ \\
\hline Logatec & 536.9 & 6411 & 83.7 & 59 & 536.9 & 6411 & 83.7 & 59 & 95.8 & PS \\
\hline Maribor & 12013.4 & 10961 & 115.5 & 40 & 12338.6 & 124609 & 99 & 51 & 90.7 & $T$ \\
\hline Medvode & 1038.1 & 4655 & 223 & 6 & 1246 & 6004 & 207.5 & 8 & 3.4 & $\mathrm{~S}$ \\
\hline Mengeš & 520.1 & 5186 & 100.3 & 50 & 5201 & 5186 & 100.3 & 49 & 19.2 & PS \\
\hline Metlika & 550.5 & \begin{tabular}{|l|}
3309166 \\
\end{tabular} & 166.3 & 18 & 648.8 & 3633 & 178.3 & 13 & 91.6 & $\mathrm{~S}$ \\
\hline Mežica & 160.7 & 3747 & 42.9 & 69 & 160.7 & 3747 & 42.9 & 69 & 8.1 & $S$ \\
\hline Mur. Sobota & 2668.4 & 13857 & 192.5 & 11 & 2821.8 & 15098 & 186.9 & 11 & 82.6 & PT \\
\hline
\end{tabular}




\begin{tabular}{|c|c|c|c|c|c|c|c|c|c|c|}
\hline Muta & 249.7 & 2419 & 103.2 & 47 & 249.7 & 2419 & 103.2 & 45 & 29.6 & $\mathrm{~S}$ \\
\hline Nova Gorica & 1975 & 14638 & 134.9 & 27 & 3184.5 & 20753 & 153.4 & 20 & 53.6 & $\mathrm{~T}$ \\
\hline Novo mesto & 3801 & 22333 & 170.2 & 16 & 3801 & 22333 & 170.2 & 14 & 79.3 & PS \\
\hline Ormož & 533.5 & 2298 & 232.1 & 4 & 533.5 & 2451 & 217.6 & 3 & 75.9 & PS \\
\hline Piran & 179.4 & 4788 & 37.4 & 72 & 179.4 & 4788 & 37.4 & 72 & 13.2 & $\mathrm{~T}$ \\
\hline Pivka & 277.7 & 2105 & 131.9 & 29 & 281.4 & 2396 & 117.4 & 36 & 17.9 & $S$ \\
\hline Portorož-Lucija & 869.6 & 8499 & 102.3 & 49 & 869.6 & 8499 & 102.3 & 47 & 64.1 & $\mathrm{~T}$ \\
\hline Postojna & 904.6 & 8238 & 109.8 & 45 & 904.6 & 8238 & 109.8 & 41 & 57.8 & PT \\
\hline Prevalje & 532.4 & \begin{tabular}{l|l}
4352 \\
\end{tabular} & 122.3 & 34 & 532.4 & 4352 & 122.3 & 32 & 27 & PS \\
\hline Ptuj & 2259.7 & 11269 & 200.5 & 9 & 2352.9 & 19019 & 123.7 & 31 & 59.9 & $\mathrm{P}$ \\
\hline Radenci & 324.6 & 2215 & 146.5 & 22 & 324.6 & 2215 & 146.5 & 22 & 24.2 & $\mathrm{~S}$ \\
\hline Radeče & \begin{tabular}{l|l}
93.2 \\
\end{tabular} & 2452 & 38 & 71 & 93.2 & 2452 & 38 & 71 & 10.3 & $S$ \\
\hline Radlje ob D. & 299.9 & 2640 & 113.6 & 41 & 299.9 & 2890 & 103.7 & 44 & 35.6 & $\mathrm{P}$ \\
\hline Radovljica & 353.7 & \begin{tabular}{l|l|}
6117 \\
\end{tabular} & 57.8 & 64 & 718.5 & 9065 & 79.2 & 61 & 36.7 & $T$ \\
\hline Ravne na K. & 1034.8 & 8863 & 116.7 & 39 & 1080.8 & \begin{tabular}{l|l|}
9587 \\
\end{tabular} & 112.7 & 37 & 54.9 & $\mathrm{~S}$ \\
\hline Ribnica & 840.6 & 3302 & 254.5 & 2 & 840.6 & 3302 & 254.5 & 2 & 78.6 & PS \\
\hline Rog. Slatina & 538.9 & 4904 & 109.9 & 44 & 538.9 & 4904 & 109.9 & 40 & 56.5 & $\mathrm{~S}$ \\
\hline Ruše & 755.2 & 4705 & 160.5 & 19 & 755.2 & 4705 & 160.5 & 16 & 73.8 & $\mathrm{~S}$ \\
\hline Senovo & 106.7 & 2531 & 41.1 & 70 & 106.7 & 2531 & 42.1 & 70 & 3.6 & PS \\
\hline Sevnica & 636.7 & 5040 & 126.3 & 32 & 636.7 & 5040 & 126.3 & 28 & 65.5 & PS \\
\hline Sežana & 1037.6 & 4866 & 213.2 & 8 & 1037.6 & 4866 & 213.2 & 6 & 55.3 & PT \\
\hline Slov. Gradec & 699.8 & 6714 & 104.2 & 46 & 1046.7 & 8317 & 125.8 & 29 & 78.8 & PT \\
\hline Slov. Bistrica & 1129.4 & 6683 & 169 & 17 & 1129.4 & 6683 & 169 & 15 & 72.9 & PS \\
\hline Slov. Konjice & 680.5 & \begin{tabular}{ll|}
4882 \\
\end{tabular} & 139.4 & 26 & \begin{tabular}{l|l|}
680 \\
\end{tabular} & 4983 & 136.5 & 25 & 44.4 & $S$ \\
\hline Šempeter p.G. & 1064.7 & 3910 & 272.3 & 1 & 1064.7 & 3910 & 272.3 & 1 & 17.9 & PS \\
\hline Šentjur p. C. & 464.8 & 4518 & 102.8 & 48 & 464.8 & 4518 & 102.8 & 46 & 85.3 & PS \\
\hline Šoštanj & 562.3 & 2950 & 190.6 & 12 & 562.3 & 2950 & 190.6 & 10 & 12 & PS \\
\hline Škofja Loka & 1387.4 & 12340 & 112.4 & 42 & 1656.6 & 15442 & 107.2 & 43 & 57.4 & $\mathrm{~S}$ \\
\hline Tolmin & 196.8 & 3851 & 51.1 & 66 & 197.1 & 4035 & 48.8 & 68 & 16 & PT \\
\hline Trbovlje & 1685.5 & 17485 & 96.4 & 53 & 1685.5 & 17485 & \begin{tabular}{l|l}
96.4 \\
\end{tabular} & 52 & 93.7 & $\mathrm{~S}$ \\
\hline Trebnje & 262.8 & 2804 & 93.7 & 56 & 262.8 & 2804 & 93.7 & 55 & 36.3 & PS \\
\hline Tržič & 554.4 & 4206 & 131.8 & 30 & 692.8 & 8250 & 83.9 & 58 & 87.3 & $\mathrm{~S}$ \\
\hline Velenje & 3975 & 27337 & 145.4 & 23 & 3975 & 27337 & 145.4 & 23 & 85.4 & $\mathrm{~S}$ \\
\hline Vrhnika & 100.7 & 7019 & 99.8 & 52 & 7966 & 8689 & 91.6 & 56 & 78.1 & $S$ \\
\hline Zagorje & 445 & 7428 & $\begin{array}{r}59.9 \\
\end{array}$ & 63 & 445 & 7428 & \begin{tabular}{l|l|}
59.9 \\
\end{tabular} & 66 & 56 & $S$ \\
\hline Zreče & 630.3 & 2952 & 213.5 & 7 & 630.3 & 2952 & 213.5 & 5 & 41.1 & $\mathrm{~S}$ \\
\hline Žalec & 638.5 & 5314 & 120.1 & 37 & 638.5 & 5314 & 120.1 & 35 & 28.9 & PS \\
\hline Železniki & 569.4 & 3129 & 181.9 & 13 & 569.4 & 3129 & 181.9 & 12 & 19.7 & $\mathrm{~S}$ \\
\hline Žiri & 300.4 & 3437 & 87.4 & 58 & 300.4 & 3437 & 87.4 & 57 & 10.4 & PS \\
\hline & & & & & & & 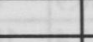 & & & \\
\hline Skupaj & 116176 & 912440 & 127.3 & & 121072 & 991611 & 122 & & 80.3 & $\mathrm{~T}$ \\
\hline
\end{tabular}




\section{GROSS DOMESTIC PRODUCT OF SLOVENIAN TOWNS}

\section{Summary}

With the year 1991, the period was terminated in Slovenia of the socialist administration and economy. Thus, the year 1991 is very convenient, so for various analyses of social and economic conditions in the past, 45 years' post-War period, as for a starting point for evaluating the development of independent Slovenia. Our attempt in the current study was to evaluate, on the basis of the data on the gross domestic product, the role and importance of Slovenian towns at the end of the socialist era. Presented are the shares of GDP that were contributed by towns and agricultural rural areas, respectively, as well as the groups of activities that were the most important. The findings should offer the evaluation of how deep the post-War urbanization and industrialization reached, and what weight can be ascribed to them.

Materials: The data on the gross domestic product made in Slovenian towns in 1990 were collected by the Statistical Office of Slovenia in accordance with the then applicable methodology. The materials included the following data: (1) GDP per commune, and (2) GDP per activity, produced in towns and other urban settlements in Slovenia. The data for each territorial unit (i.e. settlement) were divided into 14 branches. The value of GDP was stated in thousands of dinars of the then value. From the methodological point of view, several aspects of the collected materials are questionable. Above all, the data on GDP per small territorial unit raise doubts. According to the then methodology of calculating GDP, it included production in the first place, and partly only also various services, which particularly refers to the services of quaternary sector.

Territorial units. The specification of towns was a special problem. Between 1966 and 1994, Slovenia officially had no "towns", since this legal term was abandoned in the 60 's, after the introduction of the "communal" system. Because the need to specify towns still existed, such specification was made by the Republic's Statistical Office and occurred under the name of "urban settlements" (Zavod Republike Slovenije za statistiko, 1991, 1994). The list included all bigger settlements that had already been recognised as towns in the past, and some intensely urbanized settlements that were close to the towns. In this way, the list comprised 73 settlements, 58 of which were true towns and 15 were urbanized settlements.

Data analysis. The collected data on GDP were analysed according to the size categories of towns. Three groups were discerned: the first one comprised the two major towns, i.e. Ljubljana and Maribor, the second one medium-sized towns, and the third one smaller towns. Gross domestic product was divided into three groups of activities. The group of the primary activities includes the GDP produced in 
agriculture, forestry and water management. The group of the secondary activities includes the GDP produced in the manufacturing and mining industries, building industry, crafts, and private services. All other branches are comprised in the tertiary activities, and the quaternary ones as well (graph).

Results. It is evident from the data that the towns produced $80.3 \%$ of the total Slovenian GDP in 1990, which is a rather high percentage. Other settlements and agricultural areas produced the remaining $19.7 \%$ of GDP. This distribution of GDP did not correspond with the distribution of the population at all. Namely, the percentage of the population in towns and urban settlements amounted to $50.37 \%$. Obviously, the level of urbanization in economy was substantially higher than that in the population.

The second basic finding refers to the distribution of the GDP by town-size categories. The two major towns produced about $30 \%$ of GDP, medium-sized towns $(20,000$ 100,000 inhabitants) $18 \%$, and small towns (2,000-20,000 inhabitants), whose number was very great, about $31 \%$. Also in this case the disproportion to the population distribution was considerable; it was greater in the two major towns where the ratio was $30 \%$ of the GDP to $20.1 \%$ of the population, slightly lower in medium-sized towns $(18 \%$ to $10.15 \%)$, and considerable in small towns $(31 \%$ to $20.1 \%)$. The above described dichotomy could be ascribed to two reasons: 1) the division of labour is at a higher level in bigger towns, and consequently, a greater GDP is produced. 2) a lot of people from surrounding areas are employed in bigger urban settlements and their work is registered to the benefit of the towns. There is abundant labour migration in Slovenia, and most probably, the cause for these differences should be searched for in this, above all.

In 1990 , the average GDP per capita in Slovenia amounted to $76,669,000$ dinars; it was substantially higher in towns $(120,200,000$ dinars), which was by 54 index points higher than the Slovenian average.

Regional differences between the developed and less developed areas can be illustrated by another piece of information. Towns achieved a substantially greater GDP per capita than the surrounding rural areas. The ratio between the GDP per urban inhabitant and the GDP per rural inhabitant was by several times greater in the less developed areas (1:10-15) than in the developed communes (1:3-5).

The third issue we have dealt with was: Which group of activities was the most important in producing the GDP in towns? With regard to the method of collecting the data on GDP, only three groups were relevant: the primary, the secondary and the tertiary activities. They are expressed in percents of the entire Slovenian GDP: primary activities $3.46 \%$, secondary activities $55.43 \%$, tertiary activities $41.10 \%$. By division into three groups of activities and the use of the average percents it became 
possible to include numerous towns not only into one but into two groups at the same time (graph).

We can say that Slovenian towns were explicitly oriented into secondary activities, as to the GDP they produced. As a kind of peculiarity, a few towns occur which were oriented into the primary activities. Towns oriented into the tertiary activities were relatively poorly represented. As to the activity of GDP, the situation in Slovenian towns was as follows: primary $4(5.4 \%)$, primary-secondary $23(31.5 \%)$, primarytertiary $8(10.9 \%)$, secondary $30(41.1 \%)$, tertiary $8(10.9 \%)$.

The comparison between the total Slovenian GDP and the GDP produced in towns by individual branches shows that the following activities were the most urban (over $90 \%$ ): housing and public utilities, education and culture, financial and other business activities, and construction. Slightly less, $80-90 \%$ of the entire Slovenian GDP in relating fields was produced in towns by trade and crafts, while manufacturing industry in towns produced $76.8 \%$ of Slovenian industrial GDP.It can be concluded from the above stated facts that the two major towns were the only true urban centers. Medium-sized towns were less developed and they lacked explicit urban activities. Smaller towns can, in the first place, be defined as industrial centers, because they mostly lacked typical urban functions, developed above the average in trade, crafts, financial and business activities, education and medical care.

Comparison with the year 1966. Thanks to a similar methodologic approach and a similar selection of urban settlements, the data on the GDP produced in Slovenian towns in 1966 (Vrišer, 1974) render possible to compare the two periods: the peak of industrialization that Slovenia was undergoing in the mid-60's, and the end of the socialist era. The comparison reveals that the share in Slovenian GDP, produced by urban centers, increased in these 25 years from $76 \%$ (in 1966) to $80.3 \%$ (in 1990). The two major towns, Ljubljana and Maribor, kept to their share of 30\%, while the share of medium-sized towns considerably increased, from $7.3 \%$ to $18.26 \%$. As a contrast, the share of smaller towns decreased from $37.8 \%$ to $31.43 \%$. 